Article

\title{
Optimization of Agitation and Aeration for Very High Gravity Ethanol Fermentation from Sweet Sorghum Juice by Saccharomyces cerevisiae Using an Orthogonal Array Design
}

Naulchan Khongsay ${ }^{1}$, Lakkana Laopaiboon ${ }^{2,3}$, Prasit Jaisil ${ }^{4}$ and Pattana Laopaiboon ${ }^{2,5, *}$

1 Graduate School, Khon Kaen University (KKU), Khon Kaen 40002, Thailand;

E-Mail:naul_khong@hotmail.com

2 Department of Biotechnology, Faculty of Technology, Khon Kaen University (KKU),

Khon Kaen 40002, Thailand; E-Mail: lakcha@kku.ac.th

3 Fermentation Research Center for Value Added Agricultural Products (FerVAAP), Khon Kaen University (KKU), Khon Kaen 40002, Thailand

4 Department of Plant Science and Agricultural Resources, Faculty of Agriculture, Khon Kaen University (KKU), Khon Kaen 40002, Thailand; E-Mail: pjaisil@gmail.com

5 Center for Alternative Energy Research and Development (AERD), Khon Kaen University (KKU), Khon Kaen 40002, Thailand

* Author to whom correspondence should be addressed; E-Mail: patlao@kku.ac.th; Tel./Fax: +66-4336-2121.

Received: 7 December 2011; in revised form: 21 February 2012 / Accepted: 24 February 2012 / Published: 29 February 2012

\begin{abstract}
Optimization of three parameters: agitation rate (A; 100, 200 and $300 \mathrm{rpm}$ ), aeration rate $(\mathrm{B} ; 0.5,1.5$ and $2.5 \mathrm{vvm})$ and aeration timing $(\mathrm{C} ; 2,4$ and $6 \mathrm{~h})$, for ethanol production from sweet sorghum juice under very high gravity (VHG, $290 \mathrm{~g} \mathrm{~L}^{-1}$ of total sugar) conditions by Saccharomyces cerevisiae NP 01 was attempted using an $\mathrm{L}_{9}\left(3^{4}\right)$ orthogonal array design. The fermentation was carried out at $30{ }^{\circ} \mathrm{C}$ in a 2 -L bioreactor and the initial yeast cell concentration was approximately $2 \times 10^{7}$ cells $\mathrm{mL}^{-1}$. The results showed that the optimum condition for ethanol fermentation should be $A_{2} B_{3} C_{2}$ corresponding to agitation rate, $200 \mathrm{rpm}$; aeration rate, $2.5 \mathrm{vvm}$ and aeration timing, $4 \mathrm{~h}$. The verification experiments under the optimum condition clearly indicated that the aeration and agitation strategies improved ethanol production. The ethanol concentration $(P)$, productivity $\left(Q_{p}\right)$ and ethanol yield $\left(Y_{p / s}\right)$ were $132.82 \pm 1.06 \mathrm{~g} \mathrm{~L}^{-1}, 2.55 \pm 0.00 \mathrm{~g} \mathrm{~L}^{-1} \mathrm{~h}^{-1}$ and $0.50 \pm 0.00$, respectively. Under the same condition without aeration (agitation rate at $200 \mathrm{rpm}$ ), $P$ and
\end{abstract}


$Q_{p}$ were only $118.02 \pm 1.19 \mathrm{~g} \mathrm{~L}^{-1}$ and $2.19 \pm 0.04 \mathrm{~g} \mathrm{~L}^{-1} \mathrm{~h}^{-1}$, respectively while $Y_{p / s}$ was not different from that under the optimum condition.

Keywords: aeration; agitation; ethanol fermentation; orthogonal array design; Saccharomyces cerevisiae; very high gravity

\section{Introduction}

Bioethanol used as a replacement for gasoline can reduce vehicle carbon dioxide emissions by $90 \%$ [1]. It is a clean and efficient energy and widely accepted as a potential substitute for fossil fuels [2,3]. Bioethanol can be produced in biotechnological route from the fermentation of agricultural biomass by microorganisms. The most common renewable fuel today is ethanol derived from corn grain (in USA), sugarcane (in Brazil), tapioca starch and sugarcane molasses (in Thailand). It is expected that there will be a limitation of the supply of these raw materials in the near future which are directly associated with food security [3].

Sweet sorghum [Sorghum bicolor (L.) Moench] is an attractive alternative feedstock for the future supplies of bioethanol because it has a high biomass and sugar yield with high fermentable sugars (sucrose, fructose and glucose) and insoluble carbohydrates (cellulose and hemicellulose). In addition, it has been noted for its potential as an energy crop because it can be cultivated at almost all temperatures and tropical climate areas [4]. In Thailand, the average yield of sweet sorghum cultivar KKU40, 90-100 days old, is about 15-25 dry ton $\mathrm{ha}^{-1}$ [5], which is comparable to the average yield (20-30 dry ton $\mathrm{ha}^{-1}$ ) reported by Wu et al. [6].

To increase the efficiency of an existing bioethanol plant, one potential improvement is to use high sugar concentrations for fermentation to produce high ethanol levels. Increasing the ethanol concentration in the broth can significantly improve the energy efficiency by reducing the energy consumption in distillation and the amount of waste stillage produced. Very high gravity (VHG) ethanol fermentations use media containing more than $270 \mathrm{~g} \mathrm{~L}^{-1}$ of total sugars [7,8]. This technology is gradually being applied to the industry where the goals of $15-16 \%$ or more alcohol are being set in order to lower the costs [7,9]. The VHG technology has led to the production of $23.8 \%(\mathrm{v} / \mathrm{v})$ ethanol in the laboratory scale from wheat mash containing 38\% (w/v) dissolved solids [10]. However, these fermentations are rarely fast and complete due to the physiological changes within the microbial cells. Moreover, the high sugar content in the fermentation medium causes an increase in the osmotic stress, which subsequently damages the yeast cells [11]. It was reported that under the appropriate environmental and nutritional conditions, Saccharomyces cerevisiae can produce and tolerate high ethanol concentrations [12-15]. VHG fermentation process exploits the observation that the growth of S. cerevisiae is promoted and prolonged when low levels of oxygen are present and the assimilable nitrogen levels are not limited [16]. The role of a small amount of oxygen supply in improving the ethanol tolerance of yeast cells under a VHG fermentation condition has been discussed [17,18]. Yeast normally requires added oxygen to synthesize lipids (sterols and unsaturated fatty acids), which are essential for plasma membrane integrity [19-22]. Regarding the essential nutrients, yeast extract is a main nitrogen source for yeast growth. It is found to have protective effects either on growth and 
fermentation or cell viability, which stimulate the fermentation rate and ethanol production [12,23]. Laopaiboon et al. [23] and Nuanpeng et al. [24] showed that $9 \mathrm{~g} \mathrm{~L}^{-1}$ of yeast extract promoted batch ethanol production from sweet sorghum juice containing $280 \mathrm{~g} \mathrm{~L}^{-1}$ of total sugar and sugar utilization was almost complete under the agitation rate of $100 \mathrm{rpm}$ without aeration. However, a very high initial yeast cell concentration $\left(1 \times 10^{8}\right.$ cells $\left.\mathrm{mL}^{-1}\right)$ was required. Providing the adequate amount of aeration during the initial stage of fermentation may reduce the initial yeast cell concentration used and improve the ethanol tolerance of the yeast cells. Alfenore et al. [17] reported that aeration at $0.2 \mathrm{vvm}$ led to a $23 \%$ increase in the viable cell mass for fed-batch ethanol fermentation, meanwhile the ethanol production and yield were also enhanced. Aeration during the initial stage of yeast growth along with a constant agitation increased the final ethanol concentration from $128.1 \mathrm{~g} \mathrm{~L}^{-1}$ (without aeration) to $143.8 \mathrm{~g} \mathrm{~L}^{-1}$ [25]. Therefore, the ethanol fermentation under VHG conditions will be more efficient and more productive when the proper aeration strategy is implemented to enlarge a healthy propagating yeast population, resulting in higher ethanol production.

Statistical methodologies are applied in biotechnological processes to observe the main effects and interactions of the factors that play fundamental roles in the fermentations. Orthogonal array design (OAD), also known as the Taguchi method, incorporates the advantages of the simplex method and factorial design [26]. OAD notably reduces the number of tests and obtains the optimum value. It also arranges different factors for effective optimization of the experimental conditions [27,28].

The aim of this study was to optimize the three main parameters, namely agitation rate $(100,200$ and $300 \mathrm{rpm})$, aeration rate $(0.5,1.5$ and $2.5 \mathrm{vvm})$ and aeration timing $(2,4$ and $6 \mathrm{~h}$ ) for ethanol production from sweet sorghum juice under VHG fermentation by $S$. cerevisiae NP 01 using the $\mathrm{L}_{9}\left(3^{4}\right)$ orthogonal array design. Verification experiment of the corresponding parameters under the optimum condition was also carried out.

\section{Experimental Section}

\subsection{Microorganism and Inoculum Preparation}

S. cerevisiae NP 01 isolated from Loog-pang (Chinese yeast cake) from Nakhon Phanom province, Thailand was inoculated into a $250-\mathrm{mL}$ Erlenmeyer flask containing $100 \mathrm{~mL}$ of yeast extract malt extract (YM) medium. The medium contained (in $\mathrm{g} \mathrm{L}^{-1}$ ) yeast extract, 3; peptone, 5; malt extract, 3 and glucose, 10. The flask was incubated on a rotating shaker at $200 \mathrm{rpm}, 30{ }^{\circ} \mathrm{C}$ for $15 \mathrm{~h}$. To increase cell concentration, the yeast (approximately $10 \% \mathrm{v} / \mathrm{v}$ ) was then transferred into a $500-\mathrm{mL}$ Erlenmeyer flask with $350 \mathrm{~mL}$ of the sweet sorghum juice containing $150 \mathrm{~g} \mathrm{~L}^{-1}$ of total sugar concentration to give the initial cell concentration of approximately $5 \times 10^{6}$ cells $\mathrm{mL}^{-1}$. The flasks were further incubated under the same conditions. After $12 \mathrm{~h}$, the active cells were harvested and used as an inoculum for ethanol production.

\subsection{Raw Material}

Sweet sorghum juice extracted from its stalks (cv. KKU 40 modified from cv. Keller) was obtained from the Department of Plant Science and Agricultural Resources, Faculty of Agriculture, Khon Kaen University, Thailand. To avoid storage problem and to prevent bacterial contamination, the juice which 
originally contained $18^{\circ} \mathrm{Bx}$ of total soluble solids, was concentrated to $75^{\circ} \mathrm{Bx}$ and stored at $4{ }^{\circ} \mathrm{C}$ prior to use.

\subsection{Ethanol Production Medium}

The concentrated juice was diluted with distilled water to the desired total sugar concentration (290 $\mathrm{g} \mathrm{L}^{-1}$ ). Then the juice was supplemented with $9 \mathrm{~g} \mathrm{~L}^{-1}$ of yeast extract as a nitrogen supplement [23], which was used as an ethanol production (EP) medium. The EP medium was transferred into a 2-L fermenter (Biostat ${ }^{\circledR} \mathrm{B}, \mathrm{B}$. Braun Biotech, Germany) with a final working volume of $1 \mathrm{~L}$ and autoclaved at $110{ }^{\circ} \mathrm{C}$ for 40 min or it was transferred into a 5 - L fermenter $\left(\right.$ Biostat $^{\circledR} \mathrm{B}$, B. Braun Biotech, Germany) with a final working volume of $3 \mathrm{~L}$ and autoclaved at $110^{\circ} \mathrm{C}$ for $60 \mathrm{~min}$.

\subsection{Preliminary Experiments}

The EP medium (1 L) with and without $9 \mathrm{~g} \mathrm{~L}^{-1}$ of yeast extract was transferred into the 2-L fermenter and autoclaved. The inoculum (10\% inoculum size) was added into the sterile EP medium to give the initial yeast cell concentration of approximately $2 \times 10^{7}$ cells $\mathrm{mL}^{-1}$. The fermentation was operated in batch system at $30{ }^{\circ} \mathrm{C}$ under the four conditions of agitation rate, aeration rate and aeration timing (a period that the medium was aerated) as shown in Table 1. Samples were withdrawn at time intervals for analysis.

Table 1. Agitation and aeration conditions for the preliminary experiments.

\begin{tabular}{cccc}
\hline Condition & Agitation rate (rpm) & Aeration rate (vvm) & Aeration timing (h) \\
\hline 1 & 100 & - & - \\
2 & 100 & 0.5 & 2 \\
3 & 200 & - & - \\
4 & 200 & 2.5 & 6 \\
\hline
\end{tabular}

\subsection{Orthogonal Experimental Design}

The $\mathrm{L}_{9}\left(3^{4}\right)$ orthogonal table was designed to investigate the influence of the three main parameters: agitation rate $(\mathrm{A})$, aeration rate $(\mathrm{B})$ and aeration timing $(\mathrm{C})$. Each factor was set at three levels (A; 100, 200 and 300 rpm: B; 0.5, 1.5 and 2.5 vvm: C; 2, 4 and $6 \mathrm{~h}$ ). There were 9 runs in total and all of them were performed in duplicate. The $\mathrm{L}_{9}\left(3^{4}\right)$ orthogonal design is shown in Table 2. The blank factor was a dummy and was used for error estimation. In Taguchi method, orthogonal arrays and analysis of variance (ANOVA) were used as the tools of analysis. The effect of a factor on the characteristic properties was estimated by ANOVA [29,30].

\subsection{Fermentation Conditions}

The ethanol fermentation under various conditions in Table 2 was carried out in the 2-L fermenter

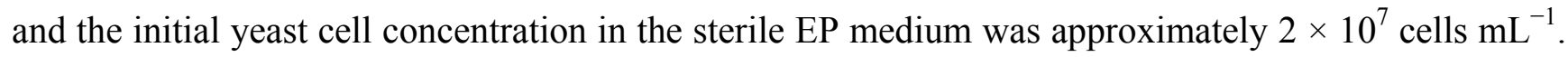
The fermentation was operated in batch mode and the temperature was controlled at $30{ }^{\circ} \mathrm{C}$. Samples were withdrawn at time intervals for analysis. To verify the reliability of the results from the 
orthogonal experiments, additional experiments under the optimum condition of the corresponding parameters were carried out in 2-L and 5-L bioreactors.

Table 2. The $\mathrm{L}_{9}\left(3^{4}\right)$ orthogonal design.

\begin{tabular}{ccccc}
\hline \multirow{2}{*}{ Run } & $\boldsymbol{A}$ & $\boldsymbol{B}$ & Blank & $\begin{array}{c}\boldsymbol{C} \\
\text { Aeration timing (h) }\end{array}$ \\
\hline 1 & Agitation rate (rpm) & Aeration rate (vvm) & & 2 \\
2 & 100 & 0.5 & 1 & 6 \\
3 & 100 & 2.5 & 3 & 6 \\
4 & 200 & 0.5 & 2 & 6 \\
5 & 300 & 1.5 & 1 & 4 \\
6 & 300 & 0.5 & 3 & 2 \\
7 & 200 & 1.5 & 3 & 4 \\
8 & 200 & 2.5 & 1 & 2 \\
9 & 300 & 2.5 & 2 & 4 \\
\hline
\end{tabular}

\subsection{Analytical Methods}

The viable yeast cell numbers and total soluble solids of the fermentation broth were determined by direct counting method using haemacytometer with methylene blue staining [31] and hand-held refractometer, respectively. The fermentation broth was centrifuged at $13,000 \mathrm{rpm}$ for $10 \mathrm{~min}$. The supernatant was then determined for residual total sugars in terms of total carbohydrate by phenol sulfuric acid method [32]. Ethanol concentration $\left(P, \mathrm{~g} \mathrm{~L}^{-1}\right)$ was analyzed by gas chromatography (Shimadzu GC-14B, Japan, Solid phase: polyethylene glycol (PEG-20M), carrier gas: nitrogen, $150{ }^{\circ} \mathrm{C}$ isothermal packed column, injection temperature $180{ }^{\circ} \mathrm{C}$, flame ionization detector temperature $250{ }^{\circ} \mathrm{C}$; C-R7 Ae plus Chromatopac Data Processor) and 2-propanol was used as an internal standard [23]. The ethanol yield $\left(Y_{p / s}\right)$ was calculated as the actual ethanol produced and expressed as $\mathrm{g}$ ethanol per $\mathrm{g}$ total sugar utilized $\left(\mathrm{g} \mathrm{g}^{-1}\right)$. The ethanol productivity $\left(Q_{p}, \mathrm{~g} \mathrm{~L}^{-1} \mathrm{~h}^{-1}\right)$ was calculated by ethanol concentration produced $\left(P, \mathrm{~g} \mathrm{~L}^{-1}\right)$ divided by fermentation time giving the highest ethanol concentration.

\section{Results and Discussion}

\subsection{Preliminary Results}

The importance of the agitation rate and aeration rate in batch ethanol fermentation from the EP medium or sweet sorghum juice under VHG $\left(290 \mathrm{~g} \mathrm{~L}^{-1}\right.$ of the total sugar) conditions by $S$. cerevisiae NP 01 was studied prior to optimization. Figure 1 shows the ethanol fermentation under the four conditions of the preliminary experiments (Table 1). Under the same agitation and aeration rates, the viable yeast cell numbers in the EP medium with and without yeast extract were similar (Figure 1A), indicating that yeast extract supplementation did not promote yeast growth. However, it markedly improved sugar consumption and ethanol production (Figure 1B,C). The results clearly indicated that yeast extract (nitrogen supplement) significantly promoted ethanol production from sweet sorghum juice under the VHG conditions. 
Figure 1. Batch ethanol fermentation from the sweet sorghum juice with $(-)$ and without (- - -) $9 \mathrm{~g} \mathrm{~L}^{-1}$ of yeast extract under the four conditions (see Table 1) of the preliminary experiments: $(\mathbf{A})=\log$ viable cell concentration; $(\mathbf{B})=$ total sugar and $(\mathbf{C})=$ ethanol concentration.
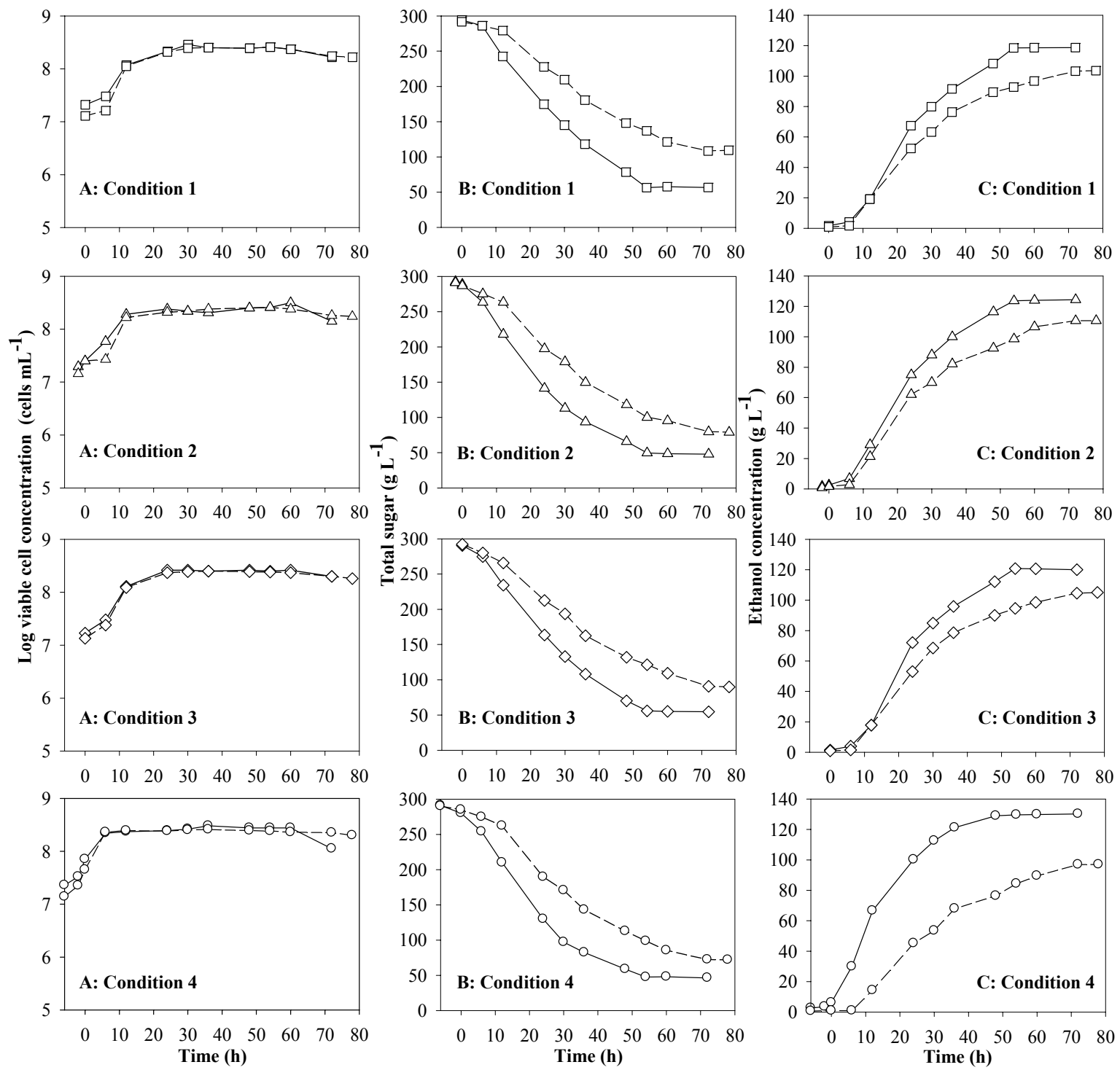

The profiles of the ethanol fermentation from the sweet sorghum juice supplemented with $9 \mathrm{~g} \mathrm{~L}^{-1}$ of yeast extract under the four conditions were then compared (Figure 2). The maximum cell concentrations of all conditions were similar (Figure 2A), but the times reaching to the maximum cell concentrations were different. Aeration made this period shorter. The periods under conditions 2 and 4 were 12 and $6 \mathrm{~h}$, respectively, while the periods of no aeration (conditions 1 and 3) were markedly longer at about $24 \mathrm{~h}$. Under the VHG conditions, the total sugars were not completely consumed by S. cerevisiae NP 01 (Figure 2B). This might be due to the osmotic stress occurred under these conditions [11]. It was found that an increase in the agitation rate only from 100 to $200 \mathrm{rpm}$ (conditions 1 and 3) did not have a positive effect on sugar consumption and ethanol production efficiencies in terms of $P, Q_{p}$ and $Y_{p / s}$ (Table 3). The agitation rate combined with the appropriate aeration rate and aeration timing promoted $S$. cerevisiae NP 01 to utilize sugar readily, leading to high 
ethanol production. The results obtained were supported by Lin et al. [33] who found that the presence of an appropriate amount of dissolved oxygen made the yeast physiologically healthy and became productive. Therefore, the optimization of the agitation rate and the aeration rate was studied in the subsequent experiments.

Figure 2. Batch ethanol fermentation from the sweet sorghum juice supplemented with $9 \mathrm{~g} \mathrm{~L}^{-1}$ of yeast extract under the four conditions (see Table 1) of the preliminary experiments: $(\mathbf{A})=\log$ viable cell concentration; $(\mathbf{B})=$ total sugar and $(\mathbf{C})=$ ethanol concentration.
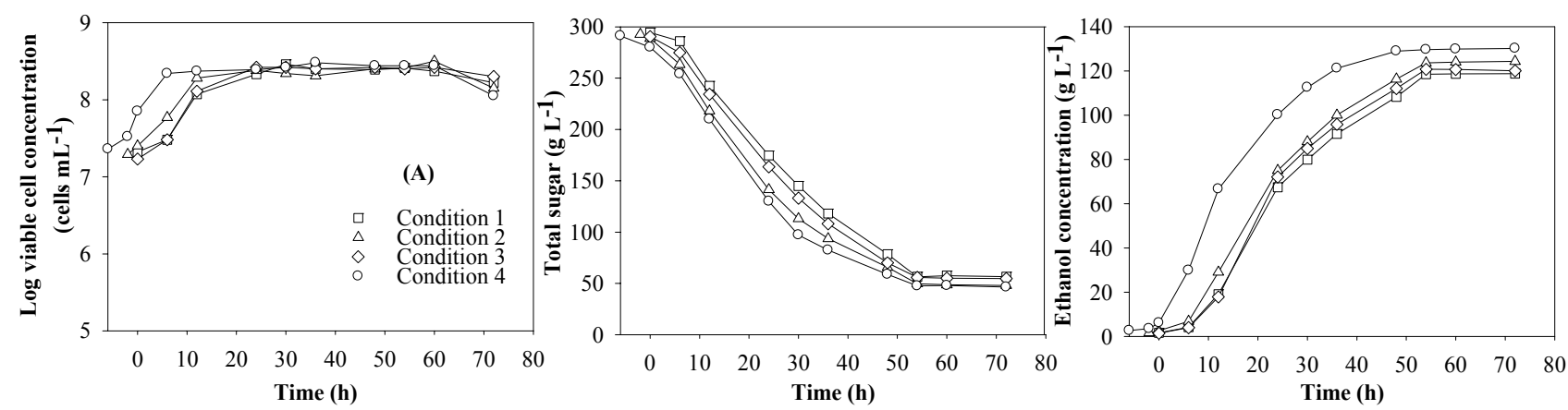

Table 3. Main fermentation parameters of batch ethanol production from the sweet sorghum juice containing $9 \mathrm{~g} \mathrm{~L}^{-1}$ of yeast extract under the four conditions of the preliminary studies.

\begin{tabular}{ccccc}
\hline Condition $^{\mathrm{a}}$ & Sugar consumption $(\%)$ & $\boldsymbol{P}\left(\mathbf{g ~ L}^{-\mathbf{1}}\right)$ & $\boldsymbol{Q}_{\boldsymbol{p}}\left(\mathbf{g ~ L}^{-1} \mathbf{h}^{-\mathbf{1}}\right)$ & $\boldsymbol{Y}_{\boldsymbol{p} / \mathrm{s}}\left(\mathbf{g ~ g}^{-\mathbf{1}}\right)$ \\
\hline 1 & $80.84 \pm 2.02^{\mathrm{b}, \mathrm{c}}$ & $119.44 \pm 1.10^{\mathrm{b}}$ & $2.21 \pm 0.02^{\mathrm{c}}$ & $0.51 \pm 0.01^{\mathrm{c}, \mathrm{d}}$ \\
2 & $83.02 \pm 1.03^{\mathrm{c}}$ & $121.33 \pm 0.60^{\mathrm{c}}$ & $1.96 \pm 0.01^{\mathrm{b}}$ & $0.47 \pm 0.01^{\mathrm{b}}$ \\
3 & $80.08 \pm 1.16^{\mathrm{b}}$ & $118.02 \pm 1.19^{\mathrm{b}}$ & $2.19 \pm 0.04^{\mathrm{c}}$ & $0.50 \pm 0.01^{\mathrm{c}}$ \\
4 & $82.29 \pm 0.94^{\mathrm{b}, \mathrm{c}}$ & $128.98 \pm 0.34^{\mathrm{d}}$ & $2.39 \pm 0.01^{\mathrm{d}}$ & $0.52 \pm 0.00^{\mathrm{d}}$ \\
\hline
\end{tabular}

$P$, ethanol concentration; $Q_{p}$, ethanol productivity and $Y_{p / s}$, ethanol yield; The experiments were performed in duplicate and the results were expressed as mean $\pm \mathrm{SD} .{ }^{\mathrm{a}}$ See Table $1 ;{ }^{\mathrm{b}, \mathrm{c}, \mathrm{d}}$ Means followed by the same letter within the same column are not significantly different using Duncan's multiple range test at the level of 0.05 .

\subsection{The Orthogonal Experiment Results of Ethanol Fermentation}

Batch ethanol fermentations of Run 1 to Run 9 (Table 2) were carried out. The results of batch ethanol fermentation of Run 1 (agitation rate, $100 \mathrm{rpm}$; aeration rate, $0.5 \mathrm{vvm}$ and aeration timing, $2 \mathrm{~h}$ ) are shown in Figure 3. At the beginning of the fermentation, the initial total sugar, $\mathrm{pH}$ and the initial cell concentrations were $292.70 \mathrm{~g} \mathrm{~L}^{-1}, 4.58$ and $1.95 \times 10^{7}$ cells $\mathrm{mL}^{-1}$, respectively. Aeration at $0.5 \mathrm{vvm}$ for the first $2 \mathrm{~h}$ caused oxygen to be soluble in the aqueous broth and the prior aerobic growth of yeast cells was extremely important to increase yeast cells and to dictate the fermentation. Hammond [34] reported that the oxygen present earlier in the fermentation was rapidly used up for the synthesis of membrane components which were essential for growth. The yeast cell numbers increased significantly in the first $12 \mathrm{~h}$ of the experiments with the value of approximately $2.0 \times 10^{8} \mathrm{cells} \mathrm{mL}^{-1}$ and slightly increased with the value of $3.14 \times 10^{8}$ cells $\mathrm{mL}^{-1}$ at $60 \mathrm{~h}$. The $\mathrm{pH}$ of the medium slightly decreased within $24 \mathrm{~h}$, and was relatively constant at about 4.0 throughout the experiment. The results 
also showed that no lag phase was observed after inoculation. The sugars were not completely consumed under this condition, with $39.83 \mathrm{~g} \mathrm{~L}^{-1}$ of the residual total sugar in the fermented broth. The ethanol concentration increased with increasing the fermentation time until $60 \mathrm{~h}$ with the value of $121.33 \pm 0.60 \mathrm{~g} \mathrm{~L}^{-1}$. In addition, $Q_{p}$ and $Y_{p / s}$ were $1.96 \pm 0.01 \mathrm{~g} \mathrm{~L}^{-1} \mathrm{~h}^{-1}$ and $0.47 \pm 0.01$, respectively. The profiles of the parameters measured during the batch ethanol fermentation of the eight remaining runs were similar to those of Run 1 (data not shown). Table 4 shows the orthogonal experiment results of $P, Q_{p}$ and $Y_{p / s}$. High $P$ and $Q_{p}$ values have been continuously pursued in the industry because significant energy savings can be achieved for the downstream distillation and waste distillate treatment. Therefore, the $P$ and $Q_{p}$ values are considered in this study to judge the ethanol production in the fermentation.

Figure 3. Batch ethanol fermentation of Run 1 (agitation rate, $100 \mathrm{rpm}$; aeration rate, $0.5 \mathrm{vvm}$ and aeration timing, $2 \mathrm{~h}$ ) from the sweet sorghum juice containing $9 \mathrm{~g} \mathrm{~L}^{-1}$ of yeast extract ( $\mathrm{O}=\log$ viable cell concentration, $\times=\mathrm{pH}, \boldsymbol{\square}=$ total sugar and $\bullet=$ ethanol concentration).

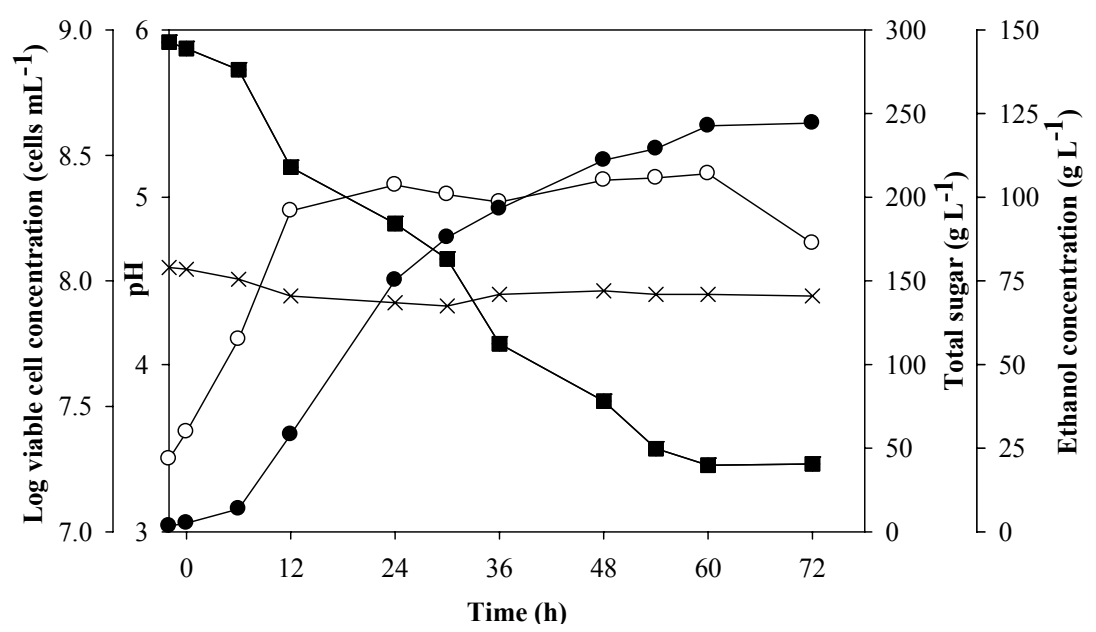

\subsection{Impact of Multi-Factors on Ethanol Concentration}

The ethanol concentrations or $P$ values varied among the combined factor treatments (Table 4) with the values ranging from $117.30 \pm 1.85$ to $131.02 \pm 0.93 \mathrm{~g} \mathrm{~L}^{-1}$. The range analysis was applied to clarify the important sequence of agitation rate (factor $A$ ), aeration rate (factor $B$ ) and aeration timing (factor $C$ ) in the orthogonal experiments (Table 5). The results showed that the range $(R)$ of factor $A$ was 8.26 , which ranked the first. Factor $C$ was 5.40, which ranked the second and factor $B$ was 2.64, which ranked the last. The bigger $R$ value of a factor represents the greater effect on the final $P$ value. According to the range, the order of influence was agitation rate $>$ aeration timing $>$ aeration rate. The optimum condition for improving $P$ value was determined as $A_{2} B_{3} C_{2}$ corresponding to agitation rate, $200 \mathrm{rpm}$; aeration rate, $2.5 \mathrm{vvm}$ and aeration timing, $4 \mathrm{~h}$. ANOVA method was used to confirm the order of the three parameters on the final $P$ value. The model $F$-value of 20.81 implied that the model was significant. There was only $4.66 \%$ chance that "a model $F$-value" this large could occur due to noise. Values of prob $F<0.05$ indicated that the model terms were significant. According to the $F$ value, the order of influences $\left(F_{\text {agitation rate }}=40.77, F_{\text {aeration timing }}=16.95\right.$ and $\left.F_{\text {aeration rate }}=4.70\right)$ was similar with that of the $R$ value. The effect of the dummy variable $\left(F_{\text {blank }}=0.55\right)$ was calculated in the 
same way as the effects of the experimental variables. If there is no interaction and no error in measuring the response, the effect shown by a dummy variable should be 0 . If not, it is assumed to be a measure of the lack of the experimental precision plus any analytical error in measuring the response [35]. The correlation between the predicted and the actual results of the ethanol concentration had $R^{2}$ of $98.42 \%$. These results confirmed an acceptable fit of the model to the data [36].

Table 4. Orthogonal experiment results of ethanol concentration $(P)$, productivity $\left(Q_{p}\right)$ and yield $\left(Y_{p / s}\right)$.

\begin{tabular}{cccc}
\hline Run $^{\mathrm{a}}$ & $\boldsymbol{P}\left(\mathbf{g ~ L}^{-1}\right)$ & $\boldsymbol{Q}_{p}\left(\mathbf{g ~ L}^{-1} \mathbf{h}^{-1}\right)$ & $\boldsymbol{Y}_{p / s}\left(\mathbf{g ~ g}^{-1}\right)$ \\
\hline 1 & $121.33 \pm 0.60^{\mathrm{c}}$ & $1.96 \pm 0.01^{\mathrm{b}}$ & $0.47 \pm 0.01^{\mathrm{b}, \mathrm{c}}$ \\
2 & $117.30 \pm 1.85^{\mathrm{b}}$ & $2.17 \pm 0.03^{\mathrm{c}}$ & $0.48 \pm 0.01^{\mathrm{b}, \mathrm{c}}$ \\
3 & $126.64 \pm 2.21^{\mathrm{d}}$ & $2.35 \pm 0.04^{\mathrm{e}}$ & $0.49 \pm 0.00^{\mathrm{c}, \mathrm{d}}$ \\
4 & $121.36 \pm 1.32^{\mathrm{c}}$ & $2.25 \pm 0.02^{\mathrm{d}}$ & $0.47 \pm 0.01^{\mathrm{b}, \mathrm{c}}$ \\
5 & $129.22 \pm 1.94^{\mathrm{e}, \mathrm{f}}$ & $2.23 \pm 0.03^{\mathrm{d}}$ & $0.51 \pm 0.01^{\mathrm{e}}$ \\
6 & $127.03 \pm 0.61^{\mathrm{d}, \mathrm{e}}$ & $2.27 \pm 0.01^{\mathrm{d}}$ & $0.48 \pm 0.01^{\mathrm{b}, \mathrm{c}}$ \\
7 & $131.02 \pm 0.93^{\mathrm{f}}$ & $2.52 \pm 0.02^{\mathrm{f}}$ & $0.50 \pm 0.00^{\mathrm{d}, \mathrm{e}}$ \\
8 & $129.27 \pm 0.39^{\mathrm{e}, \mathrm{f}}$ & $2.59 \pm 0.01^{\mathrm{g}}$ & $0.47 \pm 0.01^{\mathrm{b}, \mathrm{c}}$ \\
9 & $121.28 \pm 0.58^{\mathrm{c}}$ & $2.33 \pm 0.01^{\mathrm{e}}$ & $0.46 \pm 0.02^{\mathrm{b}}$ \\
\hline
\end{tabular}

The experiments were performed in duplicate and the results were expressed as mean $\pm \mathrm{SD}$. ${ }^{\text {a }}$ See Table 2; b,c,de,f,g Means followed by the same letter within the same column are not significantly different using Duncan's multiple range test at the level of 0.05 .

The $P$ values at different levels and factors are described in Figure 4a. They ranged from $119.97\left(k_{1}\right)$ to $128.23\left(k_{2}\right) \mathrm{g} \mathrm{L}^{-1}$ while the agitation rate was increased from 100 to $300 \mathrm{rpm}$. The highest $P$ value of $128.23 \mathrm{~g} \mathrm{~L}^{-1}\left(k_{2}\right)$ was obtained at the agitation rate of $200 \mathrm{rpm}$. Both the permeation intensity of nutrition materials from the fermentation broth to the inside of yeast cells and that of ethanol from the inside of yeast cells to the fermentation broth could be improved by increasing the agitation rate (from 100 to $200 \mathrm{rpm}$ ). These processes would enhance the sugar utilization and weaken the inhibition of the ethanol to the yeast cells [37]. However, the higher agitation rate than the stated value would not work for the improvement of ethanol concentration because of the limitation of the yeast metabolism. Therefore, the ethanol concentration did not enhance when the agitation rate exceeded $200 \mathrm{rpm}$. These findings were in agreement with those of Liu and Shen [37]. For the aeration rate tested, S. cerevisiae NP 01 showed the highest $P$ value $\left(125.86 \mathrm{~g} \mathrm{~L}^{-1}, k_{3}\right)$ at the aeration rate of $2.5 \mathrm{vvm}$. Aeration is indispensible for yeast to synthesize sterols and unsaturated fatty acids, which are essential to assure cell membrane integrity [38-40]. Additionally, aeration helps vent $\mathrm{CO}_{2}$ that inhibits the yeast growth [41]. However, an excess of aeration directs yeast towards the aerobic respiratory pathways for biomass formation, thus lowering the fermentation efficiency [42]. As a result, air may improve the synthesis of ergosterol and consequently the structural stability of cells and ethanol tolerance $[39,43]$. The maximum $P$ value of $127.17 \mathrm{~g} \mathrm{~L}^{-1}\left(k_{2}\right)$ was obtained at the aeration timing of $4 \mathrm{~h}$. It was reported that aeration during the initial stage of yeast growth along with the constant agitation possibly increased the final $P$ value up to $143.8 \mathrm{~g} \mathrm{~L}^{-1}$ from a synthetic medium containing $305 \mathrm{~g} \mathrm{~L}^{-1}$ of glucose [25]. However, the influence of combining aeration timing and aeration interval under a constant agitation rate to enhance fermentation capacity was rarely reported, particularly under VHG conditions. 
Table 5. The range analysis of $\mathrm{L}_{9}\left(3^{4}\right)$ orthogonal experiments for ethanol concentration.

\begin{tabular}{ccccc}
\hline & $\begin{array}{c}\boldsymbol{A} \\
\text { Agitation rate }\end{array}$ & $\begin{array}{c}\boldsymbol{B} \\
\text { Aeration rate }\end{array}$ & Blank & $\begin{array}{c}\boldsymbol{C} \\
\text { Aeration timing }\end{array}$ \\
\hline$K_{1}$ & 719.82 & 754.38 & 747.42 & 755.28 \\
$K_{2}$ & 769.38 & 739.32 & 754.38 & 763.02 \\
$K_{3}$ & 759.72 & 755.16 & 747.12 & 730.62 \\
$k_{1}$ & 119.97 & 125.73 & 124.57 & 125.88 \\
$k_{2}$ & 128.23 & 123.22 & 125.73 & 127.17 \\
$k_{3}$ & 126.62 & 125.86 & 124.52 & 121.77 \\
$R$ & 8.26 & 2.64 & 1.21 & 5.40 \\
$Q$ & $A_{2}$ & $B_{3}$ & & $C_{2}$ \\
\hline
\end{tabular}

Figure 4. The ethanol concentration (A) and productivity (B) at different levels and factors $(\boldsymbol{\Delta}=$ agitation rate, $\bullet=$ aeration rate and $\boldsymbol{\square}=$ aeration timing)
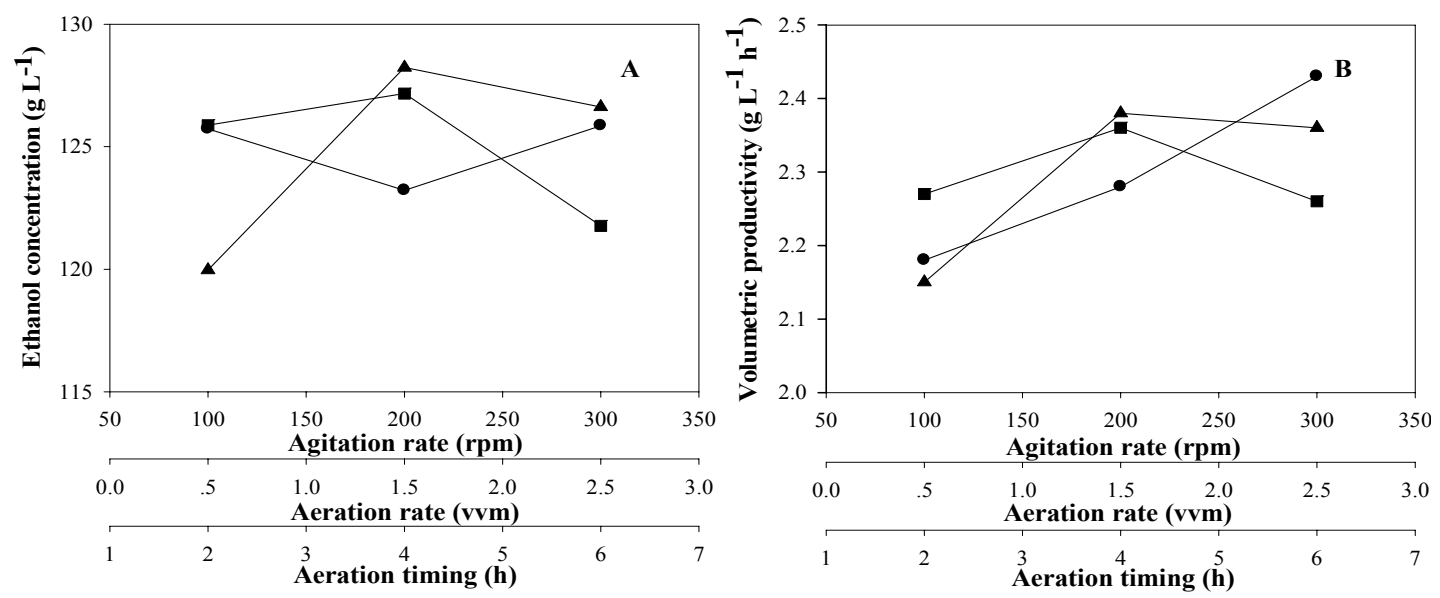

\subsection{Impact of Multi-Factors on Ethanol Productivity}

The ethanol productivity or $Q_{p}$ varied among the combined factor treatments of the orthogonal experiments in the range of $1.96 \pm 0.01$ to $2.59 \pm 0.01 \mathrm{~g} \mathrm{~L}^{-1} \mathrm{~h}^{-1}$ (Table 4). Table 6 shows the range analysis of $\mathrm{L}_{9}\left(3^{4}\right)$ orthogonal experiments of the $Q_{p}$ values. The range $(R)$ of factor $B, A$ and $C$ were $0.25,0.23$ and 0.10 , respectively. The bigger $R$ value of a factor represents the greater effect on the final $Q_{p}$. According to the range, the order of influence was aeration rate $>$ agitation rate $>$ aeration timing. The order of influence for the $Q_{p}$ value was different from that for the $P$ value. However, the optimum condition for improving $Q_{p}$ value $\left(A_{2} B_{3} C_{2}\right)$ was the same as that for $P$ value. Thus the optimum fermentation condition was determined as follows: agitation rate, $200 \mathrm{rpm}$; aeration rate, $2.5 \mathrm{vvm}$ and aeration timing, $4 \mathrm{~h}$. According to the $F$ value, the order of influence for $Q_{p}$ value $\left(F_{\text {aeration rate }}=1.649\right.$, $F_{\text {agitation rate }}=1.519$ and $\left.F_{\text {aeration timing }}=0.210\right)$ was similar to those of the $R$ value. The correlation between the predicted and actual results of the ethanol productivity having $R^{2}$ higher than $75 \%$ confirmed that the fitted model to the results was acceptable [36]. 
Table 6. The range analysis of $\mathrm{L}_{9}\left(3^{4}\right)$ orthogonal experiments for ethanol productivity.

\begin{tabular}{ccccc}
\hline & $\begin{array}{c}\boldsymbol{A} \\
\text { Agitation rate }\end{array}$ & $\begin{array}{c}\boldsymbol{B} \\
\text { Aeration rate }\end{array}$ & Blank & $\begin{array}{c}\boldsymbol{C} \\
\text { Aeration timing }\end{array}$ \\
\hline$K_{1}$ & 12.90 & 13.08 & 13.44 & 13.62 \\
$K_{2}$ & 14.28 & 13.68 & 14.52 & 14.16 \\
$K_{3}$ & 14.16 & 14.58 & 13.32 & 13.56 \\
$k_{1}$ & 2.15 & 2.18 & 2.24 & 2.27 \\
$k_{2}$ & 2.38 & 2.28 & 2.42 & 2.36 \\
$k_{3}$ & 2.36 & 2.43 & 2.22 & 2.26 \\
$R$ & 0.23 & 0.25 & 0.20 & 0.10 \\
$Q$ & $A_{2}$ & $B_{3}$ & & $C_{2}$ \\
\hline
\end{tabular}

Figure $4 \mathrm{~b}$ shows the $Q_{p}$ value under different conditions. The highest $Q_{p}$ of $2.38 \mathrm{~g} \mathrm{~L}^{-1} \mathrm{~h}^{-1}\left(k_{2}\right)$ was found at the agitation rate of $200 \mathrm{rpm}$ and kept almost invariable when the agitation rate was increased from $200 \mathrm{rpm}$ to $300 \mathrm{rpm}$. These indicated that the fermentation rate was enhanced with the increased agitation rate from $100 \mathrm{rpm}$ to $200 \mathrm{rpm}$ and kept almost constant from $200 \mathrm{rpm}$ to $300 \mathrm{rpm}$. The highest $Q_{p}$ value of $2.43 \mathrm{~g} \mathrm{~L}^{-1} \mathrm{~h}^{-1}\left(k_{3}\right)$ was obtained at the aeration rate of $2.5 \mathrm{vvm}$. There was a trend of higher $Q_{p}$ value with an increase in the aeration rate. The maximum $Q_{p}$ was $2.36 \mathrm{~g} \mathrm{~L}^{-1} \mathrm{~h}^{-1}\left(k_{2}\right)$ at the aeration timing of $4 \mathrm{~h}$. This might be explained that the $Q_{p}$ was boosted with the increased aeration timing from $2 \mathrm{~h}$ to $4 \mathrm{~h}$ but too long of the aeration timing in the aeration system might lead yeast cells to the "growth stage" and thus decreased the $Q_{p}$ value.

\subsection{Verification Experiments}

According to the analytical results of $P$ and $Q_{p}$ values, the optimum condition for improving $P$ and $Q_{p}$ values from the sweet sorghum juice under the VHG conditions by $S$. cerevisiae NP 01 was determined as $A_{2} B_{3} C_{2}$, corresponding to agitation rate, $200 \mathrm{rpm}$; aeration rate, $2.5 \mathrm{vvm}$ and aeration timing, $4 \mathrm{~h}$, respectively. To confirm the model adequacy for predicting the maximum $P$ and $Q_{p}$ values, the model was validated by carrying out the experiments in both $2-\mathrm{L}$ and 5 - $\mathrm{L}$ fermenters under the optimum condition even though this condition appeared in the orthogonal test (Run 7). Under the 2-L bioreactor at the corresponding parameters (Figure 5), at $48 \mathrm{~h}$ after stopping aeration, all parameters measured were almost constant. The viable cell numbers and the total sugar remaining in the broth were $2.85 \times 10^{8}$ cells $\mathrm{mL}^{-1}$ and $32.51 \pm 0.27 \mathrm{~g} \mathrm{~L}^{-1}$, respectively. The $P, Q_{p}$ and $Y_{p / s}$ values were $132.82 \pm 1.06 \mathrm{~g} \mathrm{~L}^{-1}, 2.55 \pm 0.00 \mathrm{~g} \mathrm{~L}^{-1} \mathrm{~h}^{-1}$ and $0.50 \pm 0.00$, respectively at the total fermentation time of $52 \mathrm{~h}$ (including $4 \mathrm{~h}$ of aeration) (Table 7). To complete the sugar consumption, the initial sugar concentration of the juice can be reduced from 290 to about $270 \mathrm{~g} \mathrm{~L}^{-1}$. For the 5-L fermenter, the $P, Q_{p}$ and $Y_{p / s}$ values measured were not significantly different from those of the 2-L fermenter (Table 7) indicating that the fermentation control system of both fermenters were the same. The control treatment operating under the same condition without aeration (agitation rate of $200 \mathrm{rpm}$ ) was also carried out in both treatments (Table 7). The results showed that under both 2-L and 5-L fermenters, the ethanol production efficiencies in terms of $P$ and $Q_{p}$ values under the optimum condition were approximately 9 to $16 \%$ higher than those of the control condition. The fermentation time under the optimum condition was shorter than that of the control treatment, which might be due to higher 
viable yeast growth under the optimum condition. The viable yeast cell concentration reached $2.81 \times 10^{8}$ cells $\mathrm{mL}^{-1}$ within $12 \mathrm{~h}$ under the optimum condition, while it reached the maximum value of $2.63 \times 10^{8}$ cells $\mathrm{mL}^{-1}$ at $24 \mathrm{~h}$ under the control condition. The yeast viability declined gradually after $54 \mathrm{~h}$ (Figure 5), which might be attributed to the ethanol accumulation in the broth. Microscopic observations illustrated that the yeast morphology changed from large $(6.79 \mu \mathrm{m})$ and lustrous at the beginning to small $(4.44 \mu \mathrm{m})$ and dull at the end of the fermentation. The change of cell composition is still under investigation. In addition, the results obtained imply that a proper aeration rate is essential as it not only augments the yeast population, but also reduces the fermentation time.

Figure 5. Batch ethanol fermentation in the 2-L fermenter under the optimum condition (agitation rate, $200 \mathrm{rpm}$; aeration rate, $2.5 \mathrm{vvm}$ and aeration timing, $4 \mathrm{~h}$ ) from the sweet sorghum juice containing $9 \mathrm{~g} \mathrm{~L}^{-1}$ of yeast extract $(\circ=\log$ viable cell concentration, $\times=\mathrm{pH}, \boldsymbol{\square}=$ total sugar and $\bullet=$ ethanol concentration).

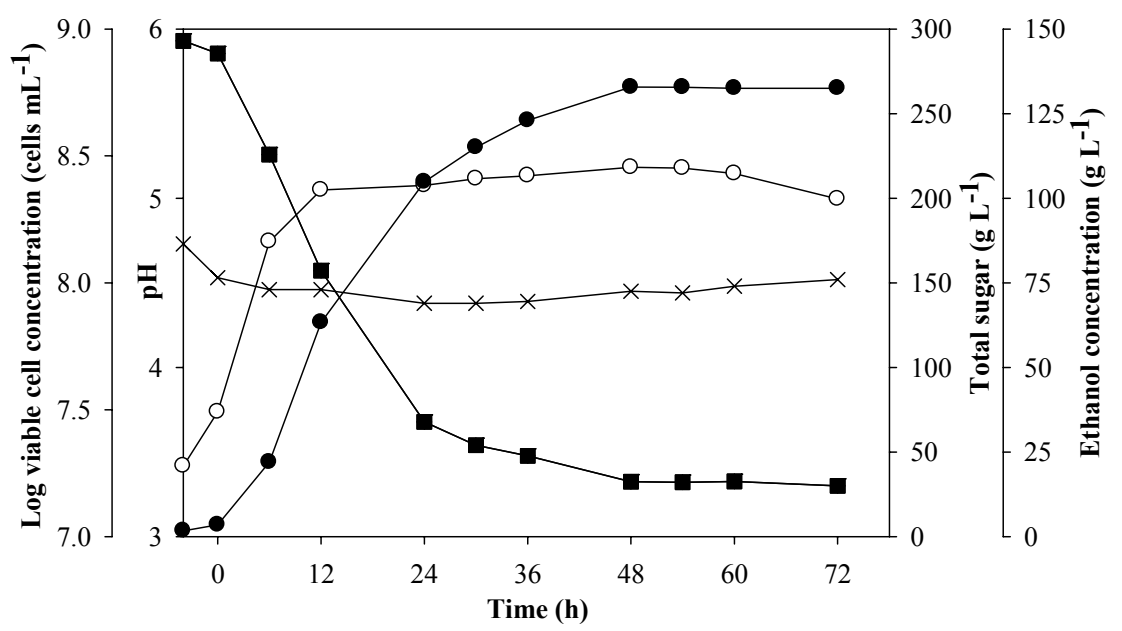

Table 7. Main fermentation parameters of batch ethanol production from the sweet sorghum juice under the optimum and control conditions.

\begin{tabular}{ccccccc}
\hline Condition & $\begin{array}{c}\text { Size of } \\
\text { Fermenter }\end{array}$ & $\begin{array}{c}\text { Sugar } \\
\text { Consumption } \\
\mathbf{( \% )}\end{array}$ & $\begin{array}{c}\boldsymbol{P} \\
\left(\mathbf{g ~ L}^{-\mathbf{1}}\right)\end{array}$ & $\begin{array}{c}\boldsymbol{Q}_{\boldsymbol{p}} \\
\left(\mathbf{g ~ L}^{-\mathbf{1}} \mathbf{h}^{-\mathbf{1}}\right)\end{array}$ & $\begin{array}{c}\boldsymbol{Y}_{\mathbf{p} / \mathbf{s}} \\
\left(\mathbf{g ~ g}^{-\mathbf{1}}\right)\end{array}$ & $\begin{array}{c}\mathbf{t} \\
\mathbf{( h )}\end{array}$ \\
\hline Optimum & $2-\mathrm{L}$ & $89.94 \pm 0.51^{\mathrm{a}}$ & $132.82 \pm 1.06^{\mathrm{a}}$ & $2.55 \pm 0.00^{\mathrm{a}}$ & $0.50 \pm 0.00^{\mathrm{a}}$ & 52 \\
\cline { 2 - 7 }$\left(A_{2} B_{3} C_{2}\right)$ & $5-\mathrm{L}$ & $88.41 \pm 1.57^{\mathrm{a}}$ & $129.72 \pm 2.03^{\mathrm{a}}$ & $2.50 \pm 0.04^{\mathrm{a}}$ & $0.50 \pm 0.00^{\mathrm{a}}$ & 52 \\
\hline \multirow{2}{*}{ Control } & $2-\mathrm{L}$ & $80.08 \pm 1.16^{\mathrm{b}}$ & $118.02 \pm 1.19^{\mathrm{b}}$ & $2.19 \pm 0.04^{\mathrm{b}}$ & $0.50 \pm 0.01^{\mathrm{a}, \mathrm{b}}$ & 54 \\
\cline { 2 - 7 } & $5-\mathrm{L}$ & $78.97 \pm 1.75^{\mathrm{b}}$ & $120.72 \pm 1.37^{\mathrm{b}}$ & $2.24 \pm 0.03^{\mathrm{b}}$ & $0.52 \pm 0.01^{\mathrm{b}}$ & 54 \\
\hline
\end{tabular}

$P$, ethanol concentration; $Q_{p}$, ethanol productivity; $Y_{p / s}$, ethanol yield and $t$, fermentation time. The experiments were performed in duplicate and the results were expressed as mean \pm SD. ${ }^{\mathrm{a}, \mathrm{b}}$ Means followed by the same letter within the same column are not significantly different using Duncan's multiple range test at the level of 0.05 . 


\section{Conclusions}

The production of ethanol as an alternative fuel from sweet sorghum juice by $S$. cerevisiae NP 01 is promising. In order to attain higher ethanol concentrations and productivity, the main parameters of ethanol fermentation, i.e., agitation rate, aeration rate and aeration timing should be optimized. The prior aerobic growth of yeast cells was extremely important to increase the cell numbers and to dictate the fermentation. Under the optimum condition (agitation rate, $200 \mathrm{rpm}$; aeration rate, $2.5 \mathrm{vvm}$ and aeration timing, $4 \mathrm{~h}$ ), the ethanol concentration and productivity were significantly improved. These findings will be beneficial for ethanol production at high levels under VHG fermentation.

\section{Acknowledgments}

The authors would like to thank the Higher Education Research Promotion and National Research University Project of Thailand through Biofuels Research Cluster of Khon Kaen University (KKU), Office of the Higher Commission Education, Center for Alternative Energy Research and Development (AERD), KKU and the Fermentation Research Center for Value Added Agricultural Products (FerVAAP), Thailand for financial support. We would like to thank Assistant Paiboon Danviruthai, Faculty of Technology, KKU for providing the NP 01 strain and Associate Aroonwadee Chanawong, Faculty of Associated Medical Sciences, KKU and Preekamol Klanrit, Faculty of Technology, KKU for their internal reviews of this paper and helpful suggestions.

\section{References}

1. Ward, O.P.; Singh, A. Bioethanol technology: Developments and perspective. Adv. Appl. Microbiol. 2002, 51, 53-80.

2. Bai, F.W.; Anderson, W.A.; Moo-Young, M. Ethanol fermentation technologies from sugar and starch feedstocks. Biotechnol. Adv. 2008, 26, 89-105.

3. Pokhrel, C.P.; Yadav, R.K.P.; Ohga, S. Agricultural waste residues as potential sources of bioethanol. Sci. World 2008, 6, 19-23.

4. Bennett, A.S.; Anex, R.P. Production, transportation and milling costs of sweet sorghum as a feedstock for centrifuged bioethanol production in the upper Midwest. Bioresour. Technol. 2009, 100, 1595-1607.

5. Jaisil, P.; Pakdee, P.; Pothisoong, T.; Lertprasert-rat, K. Production cost of sweet sorghum (Sorghum bicolor (L.) Moench) and syrup production for ethanol plant. J. Natl. Res. Counc. Thail. 2009, 148-156.

6. Wu, X.; Staggenborg, S.; Propheter, J.L.; Rooney, W.L.; Yu, J.; Wang, D. Features of sweet sorghum juice and their performance in ethanol fermentation. Ind. Crop Prod. 2010, 31, 164-170.

7. Bayrock, D.P.; Ingledew, W.M. Application of multistage continuous fermentation for production of fuel alcohol by very-high-gravity fermentation technology. J. Ind. Microbiol. Biotechnol. 2001, 27, 87-93.

8. Khongsay, N.; Laopaiboon, L.; Laopaiboon, P. Growth and batch ethanol fermentation of Saccharomyces cerevisiae on sweet sorghum stem juice under normal and very high gravity conditions. Biotechnology 2010, 9, 9-16. 
9. Bai, F.W.; Chen, L.J.; Zhang, Z.; Anderson, W.A.; Moo-Young, M. Continuous ethanol production and evaluation of yeast cell lysis and viability loss under very high gravity medium conditions. J. Biotechnol. 2004, 110, 287-293.

10. Thomas, K.C.; Hynes, S.H.; Jones, A.M.; Ingledew, W.M. Production of fuel alcohol from wheat by VHG technology: effect of sugar concentration and fermentation temperature. Appl. Biochem. Biotechnol. 1993, 43, 211-226.

11. Ozmichi, S.; Kargi, F. Ethanol fermentation of cheese whey powder solution by repeated fed-batch operation. Enzyme Microb. Technol. 2007, 41, 169-174.

12. Bafrncová, P.; Šmogrovičová, D.; Sláviková, I.; Pátková, J.; Dőmény, Z. Improvement of very high gravity ethanol fermentation by media supplementation using Saccharomyces cerevisiae. Biotechnol. Lett. 1999, 21, 337-341.

13. Watanabe, M.; Tamura, K.; Magbanua, J.P.; Takano, K.; Kitamoyo, K.; Kitagaki, H.; Akao, T.; Shimoi, H. Elevated expression of genes under the control of stress response element (STRE) and Msn2p in an ethanol tolerate sake yeast Kyokai No.11. J. Biosci. Bioeng. 2007, 104, 163-170.

14. Liu, S.; Qureshi, N. How microbes tolerate ethanol and butanol. New Biotechnol. 2009, 26, $117-121$.

15. Badotti, F.; Belloch, C.; Rosa, C.A.; Barrio, E.; Querol, A. Physiological and molecular characterization of Saccharomyces cerevisiae cachaça strains isolated from different geographic regions in Brazil. World J. Microbiol. Biotechnol. 2010, 26, 579-587.

16. Casey, G.P.; Magnus, C.A.; Ingledew, W.M. High-gravity brewing: effects of nutrition on yeast composition, fermentative ability, and alcohol production. Appl. Environ. Microbiol. 1984, 48, 639-646.

17. Alfenore, S.; Cameleyre, X.; Benbadis, L.; Bideaux, C.; Uribelarrea, J-L.; Goma, G.; Molina-Jouve, C.; Guillouet, S.E. Aeration strategy: a need for very high ethanol performance in Saccharomyces cerevisiae fed-batch process. Appl. Microbiol. Biotechnol. 2004, 63, 537-542.

18. Patrascu, E.; Rapeanu, G.; Hopulele, T. Current approaches to efficient biotechnological production of ethanol. Innovat. Rom. Food Biotechnol. 2009, 4, 1-11.

19. Márquezt, T.; Millánt, C.; Salmon, J.M. Plasma membrane sterols are involved in yeast's ability to adsorb polyphenolic compounds resulting from wine model solution browning. J. Agric. Food Chem. 2009, 57, 8026-8032.

20. Breisha, G.Z. Production of 16\% ethanol from 35\% sucrose. Biomass Bioenerg. 2010, 34, 1243-1249.

21. Jacquier, N.; Schneiter, R. Ypk1, the yeast orthologue of the human serum-and glucocorticoidinduced kinase, is required for efficient uptake of fatty acids. J. Cell Sci. 2010, 123, 2218-2227.

22. Landolfo, S.; Zara, G.; Zara, S.; Budroni, M.; Ciani, M.; Mannazzu, I. Oleic acid and ergosterol supplementation mitigates oxidative stress in wine strains of Saccharomyces cerevisiae. Int. J. Food Microbiol. 2010, 141, 229-235.

23. Laopaiboon, L.; Nuanpeng, S.; Srinophakun, P.; Klanrit, P.; Laopaiboon, P. Ethanol production from sweet sorghum juice using very high gravity technology: Effects of carbon and nitrogen supplementations. Bioresour. Technol. 2009, 100, 4176-4182.

24. Nuanpeng, S.; Laopaiboon, L.; Srinophakun, P.; Klanrit, P.; Jaisil, P.; Laopaiboon, P. Ethanol production from sweet sorghum juice under very high gravity conditions: Batch, repeated-batch and scale up for fermentation. Electron. J. Biotechnol. 2011, 14, 1-12. 
25. Liu, Y.; Qi, T.; Shen, N.; Gan, M.; Jin, Y.; Zhao, H. Improvement of ethanol concentration and yield by initial aeration and agitation culture in very high gravity fermentation. Chin. J. Appl. Environ. Biol. 2009, 15, 563-567.

26. Taguchi, G. System of Experimental Design; Krus International Press: New York, NY, USA, 1990.

27. Ke, W.; Jiuyu, H.; Lei, W.; Huimin, L. Phase factor sequences algorithm in partial transmit sequence. Trans. Tianjin Univ. 2009, 15, 23-26.

28. Yang, L.J.; Qi, Y.M.; Dang, X.N. Design and optimization of technology and structure parameters for sheet metal drawing by orthogonal experiment. Adv. Mater. Res. 2011, 295, 1714-1717.

29. Park, S.H. Robust Design and Analysis for Quality Engineering; Chapman \& Hall Press: London, UK, 1996.

30. Farzaneh, A.; Ehteshamzadeh, M.; Mohammadi, M. Corrosion performance of the electroless Ni-P coatings prepared in different conditions and optimized by the Taguchi method. J. Appl. Electrochem. 2010, 41, 19-27.

31. Zoecklien, B.W.; Fugelsang, K.C.; Gump, B.H.; Nury, F.S. Wine Analysis and Production; Chapman \& Hall Press: New York, NY, USA, 1995.

32. Mecozzi, M. Estimation of total carbohydrate amount in environmental samples by the phenol sulphuric acid method assisted by multivariate calibration. Chemom. Intel. Lab. Syst. 2005, 79, 84-90.

33. Lin, Y.H.; Chien, W.S.; Duan, K.J.; Chang, P.R. Effect of aeration timing and interval during very-high-gravity ethanol fermentation. Process Biochem. 2011, 46, 1025-1028.

34. Hammond, J. Yeast growth and nutrition. In Brewing Yeast Fermentation Performance; Smart, K., Ed.; Oxford Brookes University Press: Oxford, UK, 2000.

35. Stowe, R.E.; Mayer, R.P. Efficient screening of process variables. Ind. Eng. Chem. 1966, 56, 36-40.

36. Jangchud, A. Product optimization. In Statistics for Product Development and Application; Kasetsart University: Bangkok, Thailand, 2006; pp. 241-288.

37. Liu, R.; Shen, F. Impacts of main factors on bioethanol fermentation from stalk juice of sweet sorghum by immobilized Saccharomyces cerevisiae (CICC 1308). Bioresour. Technol. 2008, 99, 847-854.

38. Fornairon-Bonnefond, C.; Demaretz, V.; Rosenfeld, E.; Salmon, J.M. Oxygen addition and sterol synthesis in Saccharomyces cerevisiae during enological fermentation. J. Biosci. Bioeng. 2002, 93, 176-182.

39. Hernández-Cortés, G.; Córdova-López, J.A.; Herrera-López, E.J.; Morán-Marroquín, G.A.; Valle-Rodríguez, J.O.V.; Díaz-Montaňo, D.M. Effect of $\mathrm{pH}$, aeration and feeding non-sterilized agave juice in a continuous agave juice fermentation. J. Sci. Food Agric. 2010, 90, 1423-1428.

40. Liu, C.G.; Lin, Y.H.; Bai, F.W. Development of redox potential-controlled schemes for very-high-gravity ethanol fermentation. J. Biotechnol. 2011, 153, 42-47.

41. Kuhbeck, F.; Muller, M.; Back, W.; Kurz, T.; Krottenthaler, M. Effect of hot trub and particle addition on fermentation performance of Saccharomyces cerevisiae. Enzyme Microb. Technol. 2007, 41, 711-720.

42. Briggs, D.E.; Boulton, C.A.; Brookes, P.A.; Stevens, R. Brewing: Science and Practice; Woodhead Press: Cambridge, UK, 2004. 
43. Andreasen, A.A.; Stier, T.J. Anaerobic nutrition of Saccharomyces cerevisiae. I. Ergosterol requirement for growth in a defined medium. J. Cell Comp. Physiol. 1953. 43, 23-36.

(C) 2012 by the authors; licensee MDPI, Basel, Switzerland. This article is an open access article distributed under the terms and conditions of the Creative Commons Attribution license (http://creativecommons.org/licenses/by/3.0/). 